\title{
The 2011 National Science Foundation Political Science Awards
}

\begin{abstract}
$\mathrm{T}$ he Political Science Program at the National Science Foundation (NSF) announces it awards for basic research support and dissertation improvement grants for fiscal year 2011. The Program funded 25 new projects and 44 doctoral dissertation improvement proposals. The Political Science Program spent \$5,234,470 on these research, training and workshop projects and $\$ 483,822$ on dissertation training grants for political science students. The program holds two grant competitions annually -Regular Research, August and January 15; Dissertation Improvement, September 16 and January 15- and constitutes a major source of political science research funding as part of fulfilling NSF's mission to encourage theoretically focused empirical investigations aimed at improving the explanation of fundamental social and political processes and structures.
\end{abstract}

\section{REGULAR AWARDS}

With regular awards, the first principal investigator for each project is listed.

Bowler, Shaun, University of California, Riverside, "The causes and consequences of opinion formation in direct democracy elections"

Box-Steffensmeier, Janet M., Ohio State University, "Collaborative Research: The Evolution and Influence of Interest Group Networks before the Supreme Court" (co-funded with the Law and Social Science Program)

Cameron, Charles, Princeton University, "Collaborative Research: Effectiveness, Control and Competence in Public Agencies" (co-funded with the Innovation and Organizational Science Program)

Carrubba, Clifford J., Emory University, "Collaborative: Using Roll Call Votes to Understand Legislative Behavior"

Christenson, Dino, Boston University, "Collaborative Research: The Evolution and Influence of Interest Group Networks before the Supreme Court" (co-funded with the Law and Social Science Program)

Cohen, Dara K., University of Minnesota, Twin Cities, "Gender-Based Violence in Armed Conflict"

Crisp, Brian F., Washington University, "Collaborative: Using Roll Call Votes to Understand Legislative Behavior"

de Figueiredo, John M., Duke University, "Collaborative Research: Effectiveness, Control and Competence in Public Agencies" (co-funded with the Innovation and Organizational Science Program)

Elman, Colin, Syracuse University, "Support for Institutes and Research Groups on Qualitative and Multi-Method Research" (Co-funded with the Mea- sure, Methodology and Statistics Program)

Elman, Colin, Syracuse University, "Qualitative Data Repository"

Engstrom, Eric J., University of California-Davis, "Collaborative Research: Causes and Consequences of the American Ballot"

Franzese, Robert J., University of Michigan Ann Arbor, "WORKSHOP: Support for Conferences and Mentoring in Political Methodology" (Co-funded with the Measure, Methodology and Statistics Program)

Gingerich, Daniel W., University of Virginia Main Campus, "Can Institutions Cure Clientelism?"

Hillygus, D. Sunshine, Duke University, "Workshop on Questionnaire Design Issues in Longitudinal and Repeated Cross-sectional Surveys: Balancing Continuity and Innovation at Duke University in February 2011"

Ishiyama, John, University of North Texas, "REU Site: Civil Conflict Management and Peace Science" (co-funded with the Cross Directorate Activities Program)

Lemke, Douglas, Pennsylvania State University, "De Facto States in World Politics"

Lewis, David, Vanderbilt University, "Collaborative Research: Effectiveness, Control, and Competence in Public Agencies" (co-funded with the Innovation and Organizational Science Program)

Mahoney, Christine, University of Virginia Main Campus, "Framing Policy Debates in the European Union"

McCarty, Nolan, Princeton University, "Collaborative Research: The Mapping of American Legislatures"

McClain, Paula D., Duke University, "WORKSHOP: Enhancing Research: A
Workshop for Political Scientists from Underrepresented Groups"

McDaniel, Eric L., University of Texas at Austin, "Worldviews Project"

Miguel, Edward A., University of California, Berkeley, "Working Group in African Political Economy (WGAPE) Conferences" (co-funded with the Economics Program)

Moore, Will H., Florida State University, "Undergraduate Research Assistance: Data on Human Rights Violations"

Paolino, Philip, University of North Texas, "A Panel Study of the Effects of Long-Term Unemployment upon Individualist Values"

Plutzer, Eric, Pennsylvania State University, "Multi-Level Policy Responsiveness to Public Opinion"

Roberts, Jason M., University of North Carolina, Chapel Hill, "Collaborative Research: Causes and Consequences of the American Ballot"

Shor, Boris, University of Chicago, "Collaborative Research: The Mapping of American Legislatures"

Stam, Allan, University of Michigan, Ann Arbor, "Management of Complex Data Structures: Upgrades to EUGene data software"

Vavreck, Lynn, University of California, Los Angeles, "Increasing Power \& Decreasing Costs: A New Method for Drawing High-Quality National Probability Samples of U.S. Citizens" (Cofunded with the Measure, Methodology and Statistics Program) 
DOCTORAL DISSERTATION

\section{AWARDS}

With Doctoral Dissertation Research Improvement Grants, the adviser is listed fist and the student is listed second.

Adler, Scott and Joshua M. Ryan, University of Colorado at Boulder, "Doctoral Dissertation Research in Political Science: Interchamber Bargaining in Congress and the States"

John H. Aldrich and Christopher DeSante, Duke University, "Doctoral Dissertation Research in Political Science: Values and Attitudes"

Beissinger, Mark R. and Sarah J. Hummel, Princeton University, "Doctoral Dissertation Research in Political Science: Water and Energy Bargaining in Post-Soviet Central Asia”

Bickers, Kenneth N. and Scott L.

Minkoff, University of Colorado, Boulder, "Doctoral Dissertation Research in Political Science: The Proximate Polity: Exit, Space, and Networks in Local Development Politics"

Blattman, Christopher and Robert Blair, Yale University, "Doctoral Dissertation Research in Political Science: From Peacekeeping to State-Building: Governance, Violence, and the Withdrawal of the United Nations Mission in Liberia"

Brooks, Sarah M. and Scott R. Powell, Ohio State University, "Doctoral Dissertation Research in Political Science: Shifting the Employment Burden: The Social and Economic Foundations of Employment Policy Reform"

Bueno de Mesquita, Bruce and Thomas Zeitzoff, New York University, "Doctoral Dissertation Research in Political Science: The Effect of Anger and Sadness on Vengeance: A Laboratory in the Field Experiment in East Jerusalem"

Burns, Nancy E. and Walter Gong, University of Michigan, Ann Arbor, "Doctoral Dissertation Research in Political Science: Political Participation and the Blogoshere"

Carsey, Thomas M. and Jeffrey J. Harden, University of North Carolina, Chapel Hill, "Doctoral Dissertation Research in Political Science: Multidimensional Democracy: The Supply and Demand of Political Representation"

Crisp, Brian and Joshua D. Potter, Washington University, "Doctoral Dissertation Research in Political Science: Party
Entry and Voter Coordination Across Electoral Systems: A Natural Experiment"

Davenport, Christian A. and Javier Osorio, University of Notre Dame, "Doctoral Dissertation Research in Political Science: The Impact of Democratization on Drug Crime"

Davenport, Christian A. and Christopher Sullivan, University of Notre Dame, "Doctoral Dissertation Research in Political Science: Organizing Oppression: Government, Politics and the Violation of Human Rights"

Depsosato, Scott W. and Saul F. Cunow, University of California, San Diego, "Doctoral Dissertation Research in Political Science: Vote Choice and Representation in Challenging Electoral Environments"

Dickson, Eric, Rebecca Morton, and Victoria Shineman, New York University, "Doctoral Dissertation Research in Political Science: Political Information and Informed Voting"

Ermakoff, Ivan and Daniel Blocq, University of Wisconsin, Madison, "Doctoral Dissertation Research in Political Science: Formation of Armed Self-Defense Groups in Civil Wars"

Feldman, Stanley and Lilliana Mason, SUNY at Stony Brook, "Doctoral Dissertation Research in Political Science: Partisan and Ideological Sorting in the United States"

Fowler, James H. and Jaime E. Settle, University of California, San Diego, "Doctoral Dissertation Research in Political Science: The Implication of Threat and Threat Perception on Political Activity"

Gay, Claudine and Porsha Cropper, Harvard University, "Doctoral Dissertation Research in Political Science: The Mobilization and De-Mobilization of Latino Identities in Reaction to Explicit and Implicit Cues"

Geva, Nehemia and Catarina Thomson, Texas A\&M University, "Doctoral Dissertation Research in Political Science: Democratic Accountability in International Relations: Domestic Pressures and Constraints for Coercive Foreign Policy"

Hellwig, Timothy T. and Danislava Marinova, Indiana University, "Doctoral Dissertation Research in Political Science: Party Instability and Democratic Elections"
Keohane, Robert O. and Lamis Abdelaaty, Princeton University, "Doctoral Dissertation Research in Political Science: Political Competition and Refugee Policy"

Keohane, Robert O. and Marina E. Henke, Princeton University, "Doctoral Dissertation Research in Political Science: International Security and the Politics of Interdependence"

Lake, David A and Yonatan Lupu, University of California, San Diego, "Doctoral Dissertation Research in Political Science: Treaty Compliance, Enforcement and Monitoring: A Preference-Based Approach"

Landa, Dimitri and Dominik Duell, New York University, "Doctoral Dissertation Research in Political Science: Political Science and Social Identity"

Lau, Richard R and Tessa Ditonto, Rutgers University, New Brunswick, "Doctoral Dissertation Research in Political Science: The Effects of Candidate Appearance on Information Search and Candidate Evaluation in Political Campaigns"

Morton, Rebecca and Andrew Bausch, New York University, "Doctoral Dissertation Research in Political Science: Democracy and War: An Experiment"

Oi, Jean C. and Xiaojun Li, Stanford University, "Doctoral Dissertation Research in Political Science: The Political Economy of China's Trade Policy"

Posner, Daniel N. and Kristen Kao, University of California, Los Angeles, "Doctoral Dissertation Research in Political Science: Voter Expectations of Candidates in Parliamentary Elections in the Middle East"

Posner, Daniel N. and Eric Kramon, University of California, Los Angeles, "Doctoral Dissertation Research in Political Science: Vote-Buying and Political Preferences in Africa"

Ramakrishnan, Kathick and Chris S Haynes, University of California, Riverside, "Doctoral Dissertation Research in Political Science: The Effect of Empathy on Public Opinion on Immigration"

Ringe, Nils and Kyle Hanniman, University of Wisconsin, Madison, "Doctoral Dissertation Research in Political Science: What Drives Subnational Borrowing Conditions? Social Spending and Government Size" 


\section{Coming \\ in the \\ NEXT \\ ISSUE}

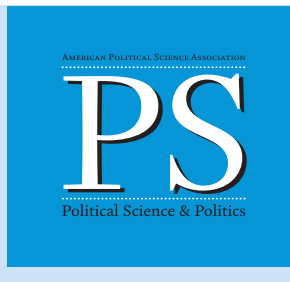

A preview of some of the articles in the April 2012 issue:

\section{SYMPOSIUM}

New Research on Gender in Political Psychology: Mentoring to Fix the Leaky Pipeline

Monica Schneider, Guest Editor

\section{FEATURES}

Reading the Tea Leaves: Understanding Tea Party Caucus Membership in the House of Representatives

Bryan T. Gervais

US Media Coverage of the Cancun Climate Change Conference Jules Boykoff

An Interesting Bias: Lessons from an Academic's Year as a Reporter David Niven

The Making of the Pundit 2010: When Strong Ties Trump Weak Ones Paul Musgrave

\section{THE TEACHER}

Umpires as Legal Realists

William Blake

Learning through Writing: Teaching Critical Thinking Skills in Writing Assignments

Gamze Cavdar

Learning Political Science with Prediction Markets: An Experimental Study Cali Mortenson Ellis

Youth, Life, and Politics: Examining the Everyday in Comparative Politics Maria Ortuoste

\section{ASSOCIATION NEWS}

Journal Reports
Robinson, James A. and Brett L Carter, Harvard University, "Doctoral Dissertation Research in Political Science: Inside Autocracy"

Sanders, Lynn M. and Katelyn L. Sack, University of Virginia Main Campus, "Doctoral Dissertation Research in Political Science: Racial and Confirmation Bias in Lie Detection"

Schatzberg, Michael G. and Barry Driscoll, University of Wisconsin, Madison, "Doctoral Dissertation Research in Political Science: The Politics of Governing Capacity"

Schickler, Eric and John Henderson, University of California, Berkeley, "Doctoral Dissertation Research in Political Science: Running on the Brand"

Shaw, Daron R. and Lance Vandenbroek, University of Texas, Austin, "Doctoral Dissertation Research in Political Science: Aversive Emotional Reasons to Politics"

Smith, Kevin B. and Amanda Balzer, University of Nebraska, Lincoln, "Doctoral Dissertation Research in Political Science: Religious and Political Beliefs at the Individual Level and Across Generations"

Smith, Steven S. and Ian Ostrander, Washington University, "Doctoral Dissertation Research in Political Science: Nominations"

Snyder, Jack L. and Emily C. Bech, Columbia University, "Doctoral Dissertation Research in Political Science: What Drives Civic Integration? Analyzing Immigrant Identity and Participation in Denmark and Sweden"
Steinfeld, Edward and Gregory Distelhorst, Massachusetts Institute of Technology, "Doctoral Dissertation Research in Political Science: Nondemocratic Accountability-Experiments with Citizen Contacting in China"

Straus, Scott and Kathleen Klaus, University of Wisconsin, Madison, "Doctoral Dissertation Research in Political Science: Claiming Land: Institutions, Narratives, and Political Violence"

Tarrow, Sidney and Robert Braun, Cornell University, "Doctoral Dissertation Research in Political Science: Social Integration and Solidarity: Evidence from the Holocaust"

Wilkinson, Steven and Shivaji Mukherjee, Yale University, "Doctoral Dissertation Research in Political Science: Why Do the Longest Civil Wars Exhibit Low-Level Violence?"

Wood, Elisabeth and Corinna Jentzsch, Yale University, "Doctoral Dissertation Research in Political Science: Counterinsurgent Militias and the Dynamics of Civil Wars"

\section{GRANTS FOR RAPID RESPONSE RESEARCH}

With RAPID awards, the first principal investigator for each project is listed.

Gibson, Clark C., University of California, San Diego, "RAPID: Election Monitoring in Africa"

Reifler, Jason A., Georgia State University, "RAPID: Assessing Voting Behavior in Elections" - 